\title{
地球規模課題対応国際科学技術協カプログラム(SATREPS) 研究課題別終了時評価報告書
}

\section{1. 研究課題名}

ガーナ由来植物による抗ウイルス及び抗寄生虫活性候補物質の研究 （2010 年 4 月一2015 年 3 月）

\section{2. 研究代表者}

2. 1. 日本側研究代表者: 山岡 昇司（東京医科歯科大学大学院医薬学総合研究科 教授）

2. 2. 相手側研究代表者：Kwadwo A. Koram（野口記念医学研究所 所長）

\section{3. 研究概要}

ガーナでは三千種を超えるハーブが自生している。ハーブを用いた感染症の予防・治療 はガーナを含むアフリカの国々に根付いた医療として有用である。本課題では、野口記念 医学研究所 (NMIMR) と生薬科学研究センター (CSRPM) の共同で、ガーナ原産薬用植物か らヒト免疫不全ウイルス（HIV）感染症とトリパノソーマ病に有効な治療薬を開発すること を目指す。具体的には、植物中の薬効成分を検出すべく抗ウイルス・寄生虫活性測定系を 確立し、その測定系を用いて活性化合物を単離同定する。得られた化合物をマウス等の動 物実験や作用機序解析に供することで目的化合物を選択する。最終的に選択化合物を用い て新規な治療薬を開発することを目標とする。

\section{4. 評価結果}

\section{総合評価 （C：問題がある（計画未達)）}

本プロジェクトは、ガーナ原産植物より感染症治療薬に有望な薬剤シードを見出すこと にある。この 5 年間で、HIV 感染症に対して既知化合物 1 種、トリパノソーマ症に対して新 規化合物を 3 種同定したが、未だ in vitroの実験結果であり、本プロジェクトの目標であ る臨床開発に繋がる可能性は低いと判断された。また、ここで見出された抗 HIV 治療薬候 補化合物は HIV 潜伏感染からのプロウイルスの再活性化を促すが、このような作用機序を 有する薬剂が実際に HIV 感染治療薬として臨床で効果を発揮しうるものか、創薬コンセプ トについて疑問が持たれる。その妥当性について事前に検証する必要があったものと思わ れる。このような活性成分の検出と単離精製は労力のかかる作業であり、薬用植物から活 性成分を単離した点は評価するが、本プロジェクトが創薬を目指す以上、早い段階で候補 化合物を評価できるシステムの開発が必要であったのではないかと見受けられる。抗トリ 
パノソーマ候補化合物を見出した点は評価されるが、化合物の有効性検証のための動物実 験が不十分であり、臨床応用に進む可能性は低いと見受けられる。

相手国へ供給した機材は、電気や実験水供給の厳しい環境にかかわらず、概ね良好に活 用されている。実験を継続できる状況にした長期専門家の努力は認める。また、CSRPM との 間に信頼関係を構築の上で、研究遂行・人材育成を積極的に進めた長崎国際大学 (NIU) の 真摰かつ熱心な対応は高く評価される。技術や人的ネットワークの構築という観点からは、 専門家や NIU を介して一定程度の技術移転とコミュニケーション強化が図られたと思われ る。

プロジェクト運営に関して、研究代表者のリーダーシップが発揮された場面は少ない。 成果が乏しいこともあり、論文や講演等の情報発信は少なかった。もう少し早い段階で化 合物情報が公表できていれば、科学的な判断も的確につけることができたと思われる。

日本政府や社会・産業への貢献度を総括するには達成度が低い。また、創薬を考えた場 合に、現化合物がそのまま製品化に結びつく可能性は極めて低いと判断された。

以上の状況を鑑みて、本課題は計画未達と判断し、C 評価とした。

\section{4-1. 地球規模課題解決への貢献}

本プロジェクトは、ガーナ原産植物の有効成分を利用して、感染症に対して効果的な治 療薬を提供することを目指して行われた。HIV 感染症に対しては結果的に、既知化合物 procyanidin に HIV 潜伏感染のプロウイルスを活性化する作用を見出した。但し、このよう な作用機序を有する薬剤が HIV 感染症治療薬として臨床的に有効か依然明確でない。創薬 コンセプトとしての妥当性については事前に検証する必要があったものと思われる。一方、 トリパノソーマ症に対しては、寄生虫増殖抑制活性を有する 3 種の新規化合物を同定し PCT 国際特許を出願している。ただマウスを用いた動物実験でこれら化合物は明確な薬効を示 しておらず、実用化の可能性は低いと見受けられる。またいずれの化合物も医薬品として の安全性や有効性・新規性に言及できる成果が得られていない。他機関から実用化の可能 性が高い薬剂が開発されるなかで、国内外の類似研究と比較してもその重要度は低く、か つ科学・技術的インパクトも弱い。

\section{4-2. 相手国ニーズの充足}

ガーナに導入した機器類については、NMIMR・CSRPM とも良く整備されており概ね活用さ れている状況にあると判断した。特に実験環境の厳しい CSRPMにおいて、電気や実験水の 安定供給に努め、実験を継続できる状況にした長期専門家の努力は認められる。

相手国の人材育成という観点からは、CSRPM の人材育成に対する長崎国際大学（NIU）の 貢献は評価される。NIU の努力により、CSRPM の研究レベルは確実に向上したと理解される。 


\section{4-3. 付随的成果}

日本政府や社会 ·産業への貢献度は低いと判断する。また、現段階で国際社会への認知 度や活用の見通しはかなり難しいと判断せざるを得ない。すでに科学的には本プロジェク トで見出された化合物を越えるものが報告されており、創薬の可能性は低いと考えられる。 科学技術の発展という観点にしても、大きな発見やブレイクスルーがあったわけでなく、 結果的に新たな展開が望める状況ではない。この 5 年間の研究により公表された具体的成 果物としての論文は in press のものを含めて僅かに 3 報である。知財としては、PCT 国際 特許が 1 報出願されたが、今後の展開次第によっては特許維持の妥当性について検討する 必要がある。

\section{4-4. プロジェクトの運営}

プロジェクトの運営面に関しては、事業を推進する上で研究代表者のリーダーシップが 効率的に発揮された場面は少なかった。ガ一ナ渡航回数も少ないことから（2３ 回程度/ 年)、十分な意見交換がなされたか懸念がある。特にプロジェクト開始当初は、日本とガー ナ間での意見の相違がみられ問題視された時期があった。研究が進むにつれて定期的なミ 一ティングも行なわれるようになりコミュニケーションも良くなったが、結果的に東京医 科歯科大学と NMIMR との間には関係改善について課題が残された。一方で、NIU と CSRPM の 間には強い信頼関係が構築されていた。

成果がそしいこともあり、論文や講演等の情報発信は少なかった。もう少し早い段階で 化合物情報等が公表できていれば、第三者的な意見の収集が可能であり、科学的な判断も 早期にできたと思われるのが残念である。

日本人の人材育成という観点からは、本プロジェクトを通してのべ 3 名の長期専門家が 関与した。途上国を良く理解し、相手国の実情を把握した上で対応できる人材を育成でき たと評価する。技術や人的ネットワークの構築という観点からは、専門家を介して一定程 度のガ一ナ側への技術移転とコミュニケーション強化が図られた。特にNIU はガーナから の研修派遣者を多く受け入れ、良好な技術交流が見られた。

\section{5. 今後の研究に向けての要改善点および要望事項}

寄生虫学部門では、新規化合物の研究を推進させるべく新たな外部予算の獲得を計画し ている。特許出願したこともありガ一ナ側研究者の期待は大きいと推察するが、単離化合 物については不明な部分が多く、今後さらに追加試験の実施が必要である。これまでに築 き上げた人的ネットワークも生かしながら、新たなデータ構築に期待したい。 
一方、NMIMR と CSRPM はいずれも機器類が整備されており、有用活性物質を検出・同定で きる環境は整っている。これらの研究機関では、今後も新たなファンディングを獲得して、 本プロジェクトにおいて整備された機材と移転された技術を有効に活用することを期待す る。

以上 


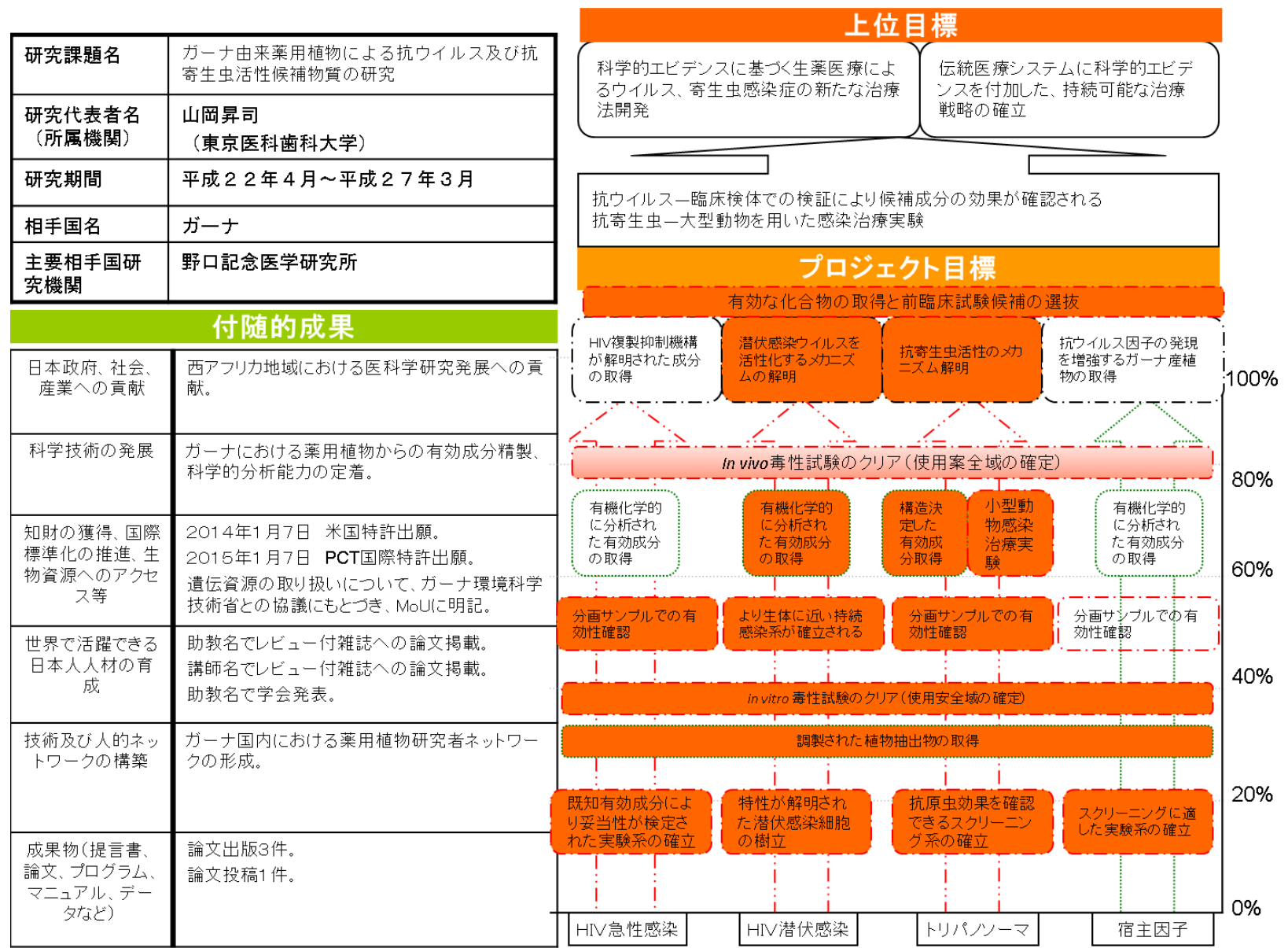

図 1 成果目標シートと達成状況（2015 年 3 月時点） 